The sound of your Bell will reverberate long, Repeated in story, and warbled in song,

A bellicose bloodless affray.

Yet although you was helplessly left in the lurch, As bell-weather heal of the militant Church;

Your brass will yet carry the day.

Perhaps you may ask, who and what am I, That thus so familiarly write? I reply,

I am naught but a jingler of ryhmes;

While you are a famed Swedenborgian wight,

Holding converse with spirits, dark-colored and light,

But squinting hard after the dimes.

Earewell 1 great polemical champion of brass,

Though by many considered a consummate ass;

Thy tale I'll no longer unfold,

For thy Keokuk proselytes now in their glory,

Might possibly hear of the wonderful story,

The last that the Bell has tolled.

W. H. T.

\title{
THE INDIAN TRIBES OF THE WEST.
}

\section{Their Language, Religion and Traditions.}

\author{
BY DR. ISAAO GALLAND.
}

[Copy-right secured.]

[We commence in this number a treatise upon theilndian character, language and traditions, and historical sketches of those of the West; selected from the posthumous papers of $\mathrm{Dr}$. Isaac Galland, and very kindly furnished us by his son, William ${ }^{\vee}$ Galland, Esq., of Boliver, Missouri.

Dr. Galland was one of the earliest settlers of Iowa, who was much among the Indian tribes, and learned perhaps more of their customs and language than any other man of his day.

In our next number we hope to give $x$ biographical sketch of this worthy man who deserves a very kind remembrance for his valuable researches in this diff. cult field of labor.]-EDiTor.

\section{MISSISŚLIPPI.}

\section{A Brief History of its Discovery and Etymology of the Name.}

Ferdinand $V_{\text {DE }}$ Soto, an enterprising Spaniard who had accompanied Pizarro in the conquest of Peru, being stimulated by reports of the immense mineral wealth of Florida, asked and obtained leave of the King of Spain to conquer that country at his own cost. In 1539 he landed his expedi- 
tion on the Peninsula of Florida, and after two years toil and fruitless search for boundless wealth, in May, A. D. 1541, he reached the banks of the "Great River of the West"called by the Spaniards, "Rio Grande," i. e. Great River, near the 35th parallel of north latitude. De Soto is reported as having been a stern, severe man, and his repeated conflicts with the Indians on his route, precluded all social intercourse between himself and the natives of the districts through which he wandered. It is therefore probable that he never learned by what name this great river of the west was designated by the natives, but even if he had learned such name, his pride and ambition would probably have prompted him, like other European adventurers, to erase all aboriginal barbarous names, and to substitute instead thereof the names of "Saints."

De Soto was probably not above New Madrid, on this great stream, to which he gave the name of "Rio Grande"-the Great or Grand River.

In the Jesuit "Revelations" for 1670 and 1671, given by the Rev. Father Claude Dablon, he writes of the nations of the Illinois, as follows, to-wit: "As we have given the name of Outaoüaes (Ottawas) to all the savages of these countries, (i. e. about lakes Huron, Superior, \&c.,) although of different nations, because the first who appeared among the French were Outaoüaes, (Ottawas); so also it is with the name of the Illinois, very numerous, and dwelling toward the south, because the first who came to the Point," \&c., (Green Bay) "for commerce, called themselves Illinois." These people are placed in the midst of the beautiful country of which we have spoken, toward the great river named Mississippi, of which it is well to set down here what we have learned of it. It seems to act as the compass of all our lakes, taking its rise in the regions of the north, and flowing toward the south until it discharges itself into the sea, which we judge to be either the Vermilion Sea or that of Florida, since we have no knowledg: of any other great rivers near those quarters, than those which discharge themselves into these two seas. 
"Some savages have assured us that this river is so fine that for more than three hundred leagues from its mouth it is larger than that which flows before Quebec, (St. Lawrence,) which is there a league in width. Moreover, that all this great space of country is of prairie, without trees, and without wood, which obliges the inhabitants of these countries to make fires of tufts of earth, and the excrements of animals dried by the sun.-(Buffalo chips).

"Some warriors of this country who say they have gone thus far, assure us that they have seen men there shaped like the French, who cleaved the trees with large knives, and some of whom had their houses on the water. It is thus that they explain themselves in speaking of sawed planks and vessels. They say besides, that all along this great river are divers colonies of nations different in language and manners, and who all make war on each other. Some are there found who are placed on the borders of the river, but many more within-land, continuing thus to the nation of the Nadoüesse (Sioux,) who are scattered over a hundred leagues of country. It is beyond this great river that are placed the Illinois of of whom we speak, and from whom are detached those who dwell here with the Fire Nation.-(Muscotins.) The Fire Nation bears this name erroneously, calling themselves Maskoutenech, (Muscotins,) which signifies ' a land bare of trees.' (Muscutah, i. e. prairie,) such as that which this people inhabit, but because by the change of a few letters, (i. e. scuta, which signifies 'fire,' from thence it has come that they are called the Fire Nation."

In 1673 , one hundred and thirty-two years after De Soto's visit to the lower section of this mighty stream of the west, the Rev. Father, James 'Marquette, a pious French missionary from Canada, having heard of the great river of the west with its thousands of human inhabitants, to whom the sound of the Gospel had never come, and desiring to go and preach to them, having first obtained leave of M. Talon, the Intendant of Canada, he associated with himself as companions, a Monsieur Joliet, of Quebec, and five boatmen, he set forth in 
search of this great stream-not for its mines of gold, or cities of mighty wealth, but to convey to its barbarous inhabitants the inestimable treasure of the knowledge of the true God, and the atonement through his son, offered for the sins of the world.

For a period of about five years, before entering upon the dangerous and toilsome enterprise of searching for the great river of the west, Father Marquette had been advised by his fellow-laborer, Father Claude Alloney, and other missionary fathers, whose fields of labor had led them among some of the eastern bands of those nations, who inhabited the district of country, in the unexplored regions of the west. And by some of whom they had been told that "the Illinois tribe have five great villages, one of which extends for three leagues; the cabins being built in a line. When the Illinois come to the Point, (Winnebago lake,) they pass a great river, which is almost a league in width; it flows from north to south, and to so great a distance that the Illinois, who know nothing of the use of the canoe, have never as yet heard tell of the mouth; they only know that there are great nations below them," \&c. Again, one of these fathers writes: "We entered into the river which leads to the Machkoutench, (Muscotines,) called Fire Nation. This is a very beautiful river, without rapids or portages; it flows to the south-west. Along this river are numerous nations, to-wit: Oumami, (Miámi,) Kikabon, (Kickǎpoo,) Machkouteng, (Muscotine), \&c. These people are established in a very fine place, where we see beautiful plains, and level country as far as the eye reaches. Their river leads into a great river called Mississippi; it is along this river where are numerous other nations." "If," (says Father Marquett,) " the savages who have promised to make me a canoe, do not fail in their word, we will navigate this river as far as possible, in company with a Frenchman named (Joliet,) and this young man, (meaning a Shawnee Indian) that they have given me, who understands several of these languages, and possesses great facility for acquiring others." It is hardly probable," continues Marquette, "that this great 
river discharges itself in Virginia; we are more inclined to believe that it has its mouth in California."

On the 13th of May, 1673, Marquette and Joliet with their little band, in two bark canoes, with a small store of provisions, set forward on their perilous journey. After passing Green Bay they entered Fox River, which they ascended to a village occupied by Miamies, Muscotines and Kickapoos, who lived in union. Here was the boundary of western discovery, beyond which no adventurer had yet passed. The Indians on learning their proposed journey, "begged them to desist," saying, "there were Indians on that great river who would cut off their heads without the least cause; warriors who would seize them; monsters who would swallow them, canoes and all; likewise a demon, who shut the way, and buried in the waters that boil about him, all who dared to approach him," \&c. " "I thanked them for their good advice," says Marquette, "but told them I could not follow it," \&c. Having passed the portage accompanied by some of the natives, who served as guides and assisted in carrying their canoes across it, they committed themselves to the current of the "Misconsin," (Wisconsin,) "a sand-barred stream, full of islands covered with vines and bordered by meadows and groves, and pleasant slopes." Floating down this stream, on the 17th of June they entered the Mississippi, "with a joy," says Marquette, "that I cannot express." Marquette writes the name of the great western river, Mississippy, Hennepin writes it, Meschasipi ; Claude Alloney, has it Messipi ; Charlevoix, Micissipi ; others have written it, Meschasabe: this name was at that time applied exclusively to the northern portion, or rather the eastern branch of the great river of the west to which De Soto gave the name of Rio Grande, or Great River. But it was early known among the Spaniards by the name of "Hidden River." Charlevoix says that the southern portion of this great river was called by the savages 'Malbouchia,' and by the Spaniards, 'La Palissade,' from the great number of trees about its mouth." But Robert De La Salle denominated it "River Colbert," in honor of 
his patron, Jean Baptiste Colbert, minister of finance and marine. The western branch of this great river of the west which rises in the Rocky Mountains, and now bears the name Missouri from latitude $45^{\circ} 10^{\prime}$ north, and longitude $110^{\circ}$ west to its junction with the Mississippi, is much longer and has a much greater volume of water than the Mississippi or eastern branch; and its furious boiling current and whirling motion of its turbid waters, are communicated to the trunk below, through its entire course to the Gulf of Mexico; and its muddy waters are perceived by those who approach its mouth when the mariner is still out of sight of land.

From the furious boiling and whirling motion of its current, this great river, from its source in the Rocky Mountains to its confluence with the Gulf of Mexico was denominated "Pe-he-ton-oak," that is, "Habitation of Furies ;" and when the term "sepe" or "sepo," that is, "river," was added, as "Pe-ke-ton-o Sepe," that is literally "The boiling River," or river of whirlpools. This with the exceptions in favor of the variety of dialects spoken by the Algonkin or Algie tribes, was the name by which this river was known to those nations.

There are two sources from which we may trace generally the great confusion in all the Indian names of rivers, lakes, nations, places, \&c., to-wit: 1st. The actual dialectic difference in the oral pronunciation of the same name by the several different tribes, as for example, we will give the following instances:

ENGLISH.

$\begin{array}{ll}\text { River, } & \text { Se-pe, } \\ \text { Water, } & \text { Ne-pe, } \\ \text { Fire, } & \text { Shu-tah, } \\ \text { Thunder, } & \text { Al-lem-e-kee, } \\ \text { Dog, } & \text { Al-lem-o, } \\ \text { Wind, } & \text { No-tin, } \\ \text { Tree, } & \text { Mit-tik, } \\ \text { Liqnid, } & \text { Wau-poo, } \\ \text { Sleep, } & \text { Ne-pi, } \\ \text { Death, } & \text { Ne-po, } \\ \text { Great, } & \text { Kit-che, } \\ \text { Good, } & \text { Men-we, }\end{array}$

CHIPPAWA.

Sebe.

Ne-be.

Ish-ko-da.

An nem-i-kee.

An-nem-o.

No-din.

Mit-tig.

Wau-boo.

Nee-bau.

Ne-bo.

Git-che.

Min-no.

These examples might be indefinitely extended, but we will only add one more, viz : 
Heaven, in the Sauk language, is "Ap-pem-mik"; in the language of the Tavatines or Penobscot Indians of Maine and New Hampshire, it was " Spum-ke-ag" ; in the Shawnee, it is "Spim-ik-a"; in the Mohegan, it is "Spum-muck"; by the Wampanoags, of Massachusetts, Rhode Island, \&c., it was "Kee-skuk-qut," (literally, "in the sky"); in the Knistennoes or Crows, it is "Es-pem-ing"; in the Algonkin, it is "O-kisk-ski-a," i. e. (in the sky); in Chippewa, it is "Spimink"; in Esquimaux, it is "Ke-kil-la," and in the Iroquois, it is "Cau-ron-unk-yaw-ga," i. e. (in the sky).

2d. But still the most essential difference in the correct enunciation of Indian words by Europeans and other nations, will be found in the varied orthographys adopted by different writers to express the same sound as has been already shown in the varied orthography of the word "Mississippi," to-wit:

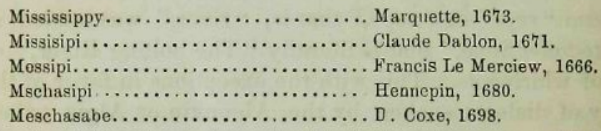

It should be borne in mind that the above named writers were all Frenchmen, (except the last named), and that they of course have adapted a French orthography to enunciate the articulate sounds uttered by the Indians in pronouncing this name.

\section{ETYMOLOGY.}

INDIAN, ENGLISH.

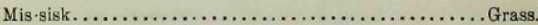

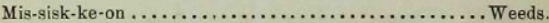

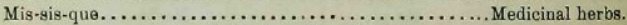

Mis-sis-ke-waw-keek, a field of exuberant herbage.

Mis-sku-tak, (meadow.) Prairie, from mis, the root of the term for herbage, and shu-tak, i. e. fire, and literally siguifies grass fire or fire of herbage.

The fitness of this name as applied to the vast native meadows of the west, has been for ages past most forcibly impressed on the beholder on witnessing the annual confligrations of the immense masses of grass and other herbage, which cover the whole face of the country; and when set on fire and accompanied with wind, presents a scene not easily 
described, and still more difficult to conceive without an actual view of the sublimity and splendor of the scene. In contemplating the beauties of a mid-summer prairie scenery, Emerson Bennett writes :

"But $\mathrm{O}$, the blooming prairie,

Here are God's floral bowers;

Of all that he hath made on earth

The loveliest.

This is the Almighty's garden

And the mountains, stars and seas

Are naught compared in beauty,

With God's garden prairie free.',

But reverse this scene of tranquil, blooming loveliness, and in autumn behold " God's floral bowers," and " garden prairie free," with all its withered loveliness, wrapt in rolling sheets of flame, which float in mountain waves across the plains, and in its destructive career sweeping every vestage of vegitation for hundreds of miles, leaving in its rear nothing but the repulsive scene of a charred black surface, throughout the whole course of its destructive march.

From these two annual scenes of vernal loveliness and autumnal devastation which the natives had witnessed from time immemorial, the former with pleasure, but the latter with terror and dismay, and which constituted the prominent destructive character of this great valley from all other countries known to the natives. And it was from those distinctive features of the country that these great native meadows were called Mis-skee-tah, as already shown, but the native tribes who occupied the country on both sides of the river were denominated Mis-shu-ten, which signifies meadow-people, or people of the meadows; while the great river which flows through those extensive meadows or fields of luxuriant herbage has in like manner received its name from the same source, as follows: Mis-sis being the two first syllables and forming the radix of Mis-sis-ke-waw-keek, which signifies meadows, or more literally, "fields of exuberant herbage," se-pe, that is river; hence the literal signification of the concrete word Mississippi, or more correctly witten Mississepe, is here shown and proved to be "The river of exuberant herbage," or river of meadows. 


\section{TRACES OF EARLY MIGRATIONS FROM THE NORTH.}

\section{Interesting Discoveries in Guatemala.}

The Abbe Brassuer de Bourbourg, says : "After the semifabulous part of the book comes the history of the passage of the Indians to these parts of America. They came from the east,-not from the south-east, but from the north-east. They came from the north-east-certainly passed through the United States, and as they say themselves, they crossed the sea in darkness, mist, cold and snow.

"Now I leave your countrymen to make all the suppositions they wish upon these strange coincidences. Who knows that the mounds and fortifications found in Western New York, Ohio, Tennessee, Arkansas, \&c., were not made by the same people, and by the colony of North-men who were known to exist in Massachusetts, and disappeared after the tenth century?"

But the most precious of my collection at present is one manuscript of the Cakchiquel language, written about three hundred years ago by one of the princes of Solola. It was never translated before, but I am now finishing a translation into French and Spanish. It is full of details on the first passage of the Indians to these countries, of their early sufferings by sea and land; of the prodigies performed by their chiefs; of the four Tulas which existed; one in the East, in darkness; one in the West, (probably that of Mexico,) one God knows where, and the last in Xibil Bay-that is to say in hell, says our reverend father Ximenes, but I have great reason to believe it was in this country.

After this, the author of the manuscript goes on with the history of his country, of the several tribes of his own blood, of the establishment and foundation of the Quiches, the Cakchiquel, Zutohil, Zokil, Rabanal, \&c., till he arrives at the times of the Conquest.

He saw Alvarado enter the capital Ximecke, now Teopan, Guatemala. He was but a boy then, but he remembers how frightful were the Spaniards-how much all the Indian princes and people were astounded at the sight of these strangers. 
He tells of all the cruelties of Alvarado; of all the princes and kings that were hanged or burned by his order-all things of which Fuentes never spoke. The author of this manuscript says, that, seeing the destruction of their books and annals, and that every record was going to ruin, he assembled in his old age the few princes that remained of his own family and of the neighboring countries, and from their books and memory he collected what he wrote in Spanish letter to be preserved by his sons.-New York Tribune.

\section{NATIVE BLACK RACE IN SOUTH AMERICA.}

There are found spread from Guyana to Choco and denominated Guaran, Iaros, Worrow, \&c., who are quite as black and as ugly as the black race in Africa, and a comparison of their language and traditions enables us to trace their origin to that continent.

The priests of the most ancient Africans called Marabous, have a tradition that after the death of Noah, his three sons, one of whom was white, the second tawney or red, the third black, agreed to divide his property fairly, which consisted of gold and silver, vestments of silk, linen and wool, horses, cattle, camels and dromedaries, besides tobacco and pipes. Having spent the greater part of the day in assorting these things, the three sons were obliged to defer the partition of the goods till the next morning. They therefore smoked a friendly pipe together, and then retired to rest, each in his own tent. After some hours sleep, the white brother awoke before the other two, being moved by avarice, arose and seized the gold and silver, together with the precious stones, and most beautiful vestments, and having loaded the best camels with them, pursued his way to that country which his white posterity have ever since inhabited.

The Moor, or tawny brother, awakening soon afterwards, with the same intentions, and being surprised that he had been anticipited by his white brother, secured in great haste the remainder of the horses, oxen and camels, and retired to 
another part of the world, leaving only some coarse vestments of cotton, pipes and tobacco, millet, rice and a few other things of small value.

The last lot of stuff fell to the share of the black son, the laziest of the three brothers, who took up his pipe with a melancholy air, and while he sat smoking in a pensive mood, swore to be revenged.-Anquetil's Universal History, Vol. $6, p .117$.

From Shem, the son of Noah, descended the Jews, together with all the other red-skins of the human race.

\section{WYANDOTTS' COSMOG0NY.}

These people, like all the other tribes of American Indians have a traditionary history of the creation of the world, animals, men, \&c., by the Great Spirit.

They believe that "God created the earth, and made men out of it. That the Indian race were created on this continent, and did not come over the sea. They were created at a place called Mountains. It was eastward. When he had made the earth and these mountains, he covered something over the earth, as it were, with his hand. Below this, he put man. All the different tribes were there.

One of the young men found his way out to the surface. He saw a great light, and was delighted with the beauty of the surface." Mountains, have been, by almost all nations of men, superstitiously regarded as the residence of the Deity ; and the above illusion to the covering over of the primitive paradise of man, bears a strong resemblance to the Mosaic history of that event.

This tradition, as recorded by Mr. Schoolcraft, proceeds as follows: "While gazing around he" (the young man who had wh found his way out to the surface of the earth,) "saw a deer wo running past with an arrow in his side. He followed it to the iar place where it fell and died. He thought it was a harmless $4 \mathrm{~m}$ looking animal. He looked back to see its track and he soon rate saw other tracks. They were the foot-prints of the person 
who had shot the deer. He soon came up. It was the Creator himself. He had taken this method to show the Indians what they must do when they come out from the earth."

This tradition of the $W$ yandotts proceeds and clearly coincides with the accounts given by other nations in reference to the following details.

1st. That the Creator taught one man the hunter's vocation; he instructed him in the art of making bows and arrows; he taught him how to hunt, kill and dress his game; he showed him how to make fire, and directed him in cooking, roasting, curing and otherwise preserving and preparing his food, and thus thoroughly inducted this young man in his new vocation, so that he could teach it to others.

2d. "God called the Indians forth out of the earth. They come in order, by tribes, and to each tribe he appointed a chief. He appointed one head chief to lead them all, who had something about his neck, and he instructed him, and put it into his head what to say to the tribes. That he might have an opportunity to do so, a certain animal was killed and a feast made, in which they were told to eat it all.

The leader God had so chosen, told the tribes what they must do to please their Maker, and what they must not do."

\section{ODJB̈WA TRADITION. From Nabinoi, an 0jibwa Chief.}

NARRATED BY MR. GEO. JOHNSON.

THEOLOGY.

About this time a person in the shape of a human being came down from the sky; his clothing was exceedingly pure and white; he was seated as it were in a nest, with a very fine cord, by which this mysterious person was let down, and the cord or string reached Heaven. He addressed the Indians in a very humane, mild and compassionate tone, saying that they were very poor and needy, but telling them that they were perpetually asleep, and this was caused by the Mache Monedo who was in the midst of them, and leading them to death and ruin. 
This mysterious personage informed them also, that above, where he came from, there was no night, that the inhabitants never slept, that it was perpetually day, and they required no sleep; that Keza-Monedo was their light. He then invited four of the Indians to ascend up with him, promising that they should be brought back in safety; that an opportunity would thereby present itself to view the beauty of the sky or heavens. But the Indians doubted and feared lest the cord should break, and did not accompany the messenger sent down to them.

This divine messenger then gave to the Indians laws and rules whereby they should be guided: 1st. To love and fear Kezha-Monedo ; 2d, That they must love one another, and be charitable and hospitable ; and $3 \mathrm{~d}$, That they must not covet their neighbor's property, but acquire it by labor and honest industry.

$\mathrm{He}$ then instituted the grand medicine or wewin dance; this ceremony was to be observed annually, and with due solemnity. But unfortunately, the foolish young men were cheated by Mache-Monedo, who caused them to adopt the Wabano dance and its ceremonies. This was finally introduced into the Meta-we-wining, (i. e. medicine dance,) and thereby corrupted it.

\section{EARLY INTERCOURSES.}

In reviewing the past history of our intercourse and relations with the Indian tribes of North America, it may be worthy of notice that our Pilgrim ancestors arrived on the American coast on the 9th of November, 1620. "In the first settlement of Plymouth, some of the company in wandering about upon discovery, came upon an Indian grave, which was that of the mother of Chik-a-taw-but, (a chief of considerable note). Over the body a stake was set in the ground, and two bear-skins sewed together, spread over it; these the English (Pilgrims) took away. When this came to the knowledge of Chik-a-taw-but, he complained to his people, and 
demanded immediate vengeance. When they were assembled he thus harrangued them: 'When last the glorious light of all the sky was underneath this globe, and birds grew silent, I began to settle, as my custom is, to take repose. Before mine eyes were fast closed, me thought I saw a vision, at which my spirit was much troubled, and trembling at that doleful sight, a spirit cried aloud, Behold my son whom I have cherished; see the paps that gave thee suck, the hands that clasped thee warm, and fed thee oft; canst thou forget to take revenge of those wild people that hath my monument defaced in a despiteful manner? disdaining our ancient antiquities and honorable customs.

See now the Sachem's grave lies like unto the common people of ignoble race, defaced; thy mother doth complain, implores thy aid against this thievish people new come hither; if this be suffered I shall not rest in quiet within my everlasting habitation."-Morton's New Canaan, 106 and 107.

Battle was the unanimous resolve, and the English were watched by the Indians until the 8 th December, 1620 . Twenty-nine days after their arrival at Cape Cod, and two days prior to their landing, at which time the first battle with the Indians was fought. We will give the account of it in the language of one of the actors:

"We went ranging up and down till the sun began to draw low, and then we hastened out of the woods that we might come to our shallop. By that time we had done and our shallop come to us, it was within night, (7th December,) and we betook us to our rest, after we had set our watch. About midnight, we heard a great and hideous cry, and our sentinel called 'Arms! arms!' So we bestirred ourselves, and shot off a couple of muskets, and the noise ceased. We concluded it was a company of wolves and foxes, for one of our company told us he had heard such a noise in Newfoundland.

About 5 o'clock in the morning (8th December,) we began to be stirring. Upon a sudden we heard a great and strange cry, which we knew to be the same voices, though they raised their notes. One of our company being abroad, came run- 
ning in and cried: 'They are men, Indians! Indians!' and withal their arrows come flying amongst us.

Our men ran out with all speed to recover their arms. The cry of our enemies was dreadful, especially when our men ran out to recover their arms. Their note was after this manner: Woach, woach, ha ha hoch woach. Our men were no sooner come to their arms but the enemy was ready to assault them. There was a lusty man, and no whit less valiant, who was thought to be their captain, stood behind a tree, within half a musket shot of us, and there let his arrows fly at us. He stood three shots of a musket. At length one of us, as he said, taking full aim at him, he gave an extraordinary cry, and away they went all."-Mount's Relation.

Although it is not certain that any blood was shed in this battle, still it is not the less interesting as being " the first encounter," and the circumstances which provoked the Indians to make the attack, have had repeated parallels in the history of our intercourse with that race, from that period up to the present time. In reference to robbing the grave of Chik-ataw-but's mother, Mount's Relation further says: "We brought sundry of the prettiest things away with us, and covered the corpse up again,-here there was a variety of opinions amongst us about the embalmed person," but does not mention the bear-skins.

When Black ${ }^{\gamma}$ Hawk and bis band were removed from their ancient town near the mouth of Rock River to the western shore of the Mississippi in 1831, the troops who were marched there for the purpose of compelling, if necessary, the Indians to remove from that place, were not careful " $t o$ cover the corpses up again!" when they had stripped them of many fine Macina blankets, broad-cloth shrouds, and many other of the "prettiest things," which were found in the graves of the Indian inhabitants of that former Metropolis of their nation. Although these incidents were separated by a lapse of 211 years, the only material defect in the parallel seems to be that the actors at the "first encountre," were pious "Pilgrims," while those at Rock River, were raw militia. 
Copyright of Annals of Iowa is the property of State of Iowa, by \& through the State Historical Society of Iowa and its content may not be copied or emailed to multiple sites or posted to a listserv without the copyright holder's express written permission. However, users may print, download, or email articles for individual use. 